\title{
Report on a Large Collection of Merope tuber Newman, 1838 (Mecoptera: Meropeidae), from Arkansas, with Notes on Collection Technique, Sex Ratio, and Male Clasper Size
}

\author{
Michael J. Skvarla, Jessica A. Hartshorn, and Ashley P. G. Dowling \\ Department of Entomology, University of Arkansas, 319 Agriculture Building, Fayetteville, AR 72701, USA \\ Correspondence should be addressed to Michael J. Skvarla; mskvarla36@gmail.com
}

Received 1 July 2014; Accepted 21 August 2014; Published 31 August 2014

Academic Editor: Russell Jurenka

Copyright (C) 2014 Michael J. Skvarla et al. This is an open access article distributed under the Creative Commons Attribution License, which permits unrestricted use, distribution, and reproduction in any medium, provided the original work is properly cited.

A large collection of earwigflies, Merope tuber, is reported from Arkansas, and flight period and sex ratio are discussed. In contrast to previous studies, earwigflies were caught more frequently in pan traps than in Malaise traps and male clasper size was found not to be bimodal.

\section{Introduction}

Merope tuber Newman, 1838, known as earwigflies or forcepflies, are uncommonly collected and have fascinated entomologists since their discovery in 1837 (Figure 1). This fascination was initially due to their presumed rarityonly 16 specimens were collected between their discovery and 1904 [1]. Since then, they have continued to receive attention due to their previously assumed basal phylogenetic position within Mecoptera, relatively unknown life history, undescribed larvae, and odd appearance relative to other Mecoptera (e.g., flattened body, opisthognathous head, and broad wings folded over the abdomen) [2,3].

Only two other extant meropeids exist: Austromerope poultoni Killington, 1933 [4], from Western Australia and Austromerope brasiliensis Machado et al., 2013 [3], from Brazil. One extinct species, Boreomerope antiqua Novokschonov, 1995 [5], is known from Middle Jurassic lacustrine claystone near Kubekovo Village in Siberia. Four extinct species of Thaumatomerope (i.e., T. madygenica Rasnitsyn, 1974, T. minuta Rasnitsyn, 1974, T. oligoneura Rasnitsyn, 1974, and T. sogdiana Rasnitsyn, 1974) were originally assigned to Meropeidae but were later reassigned to Thaumatomeropidae $[6,7]$.

Collections of $M$. tuber continue to be infrequent. Prior to 1954, it was reported only from areas in or east of the Appalachian Mountains. Since then, the known range has been extended north to southern Ontario [8-10], west to Minnesota [11, 12], Iowa [13], Missouri [14-16], Arkansas [13, 16, 17], and Kansas [13], and south to Alabama [18], Georgia [17], and Florida [19, 20]. Rather than true emigration, this range expansion is best explained by the increased use of various passive trapping techniques [14]. Merope tuber have been collected using Malaise traps, picric acid traps, European chafer traps, carbon dioxide traps, molasses traps, and glue traps $[2,12,21]$, with the most effective being Malaise traps [22].

Little is known about the life history of $M$. tuber. Adults are nocturnal and attracted to light at night and spend daylight hours under logs and stones [1, 21]. They seem to be associated with moist deciduous woodlands near water $[21,23]$, although they are occasionally caught in dry grasslands far from any stream or creek [10]. Feeding preferences are unknown, although they may be attracted to carrion [2] similar to another mecopteran, Notiothauma reedi McLachlan, 1877, which has been reported from vertebrate carrion [24]. Adults stridulate by rubbing the jugum of the forewing against the metanotum [25]. The larvae of all meropeids, including $M$. tuber, remain undescribed [26] and their discovery "is certainly the most exciting thing left to be done in the study of North American Mecoptera" [14]. 


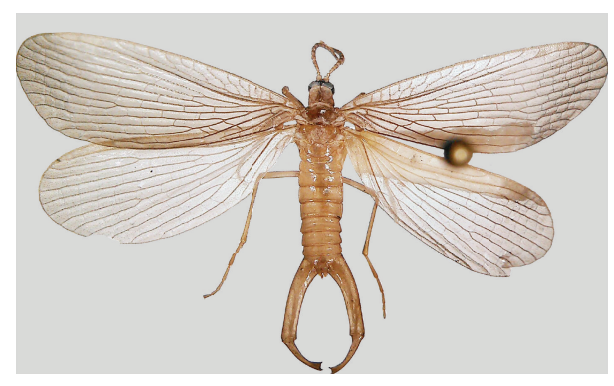

Figure 1: Merope tuber, male.

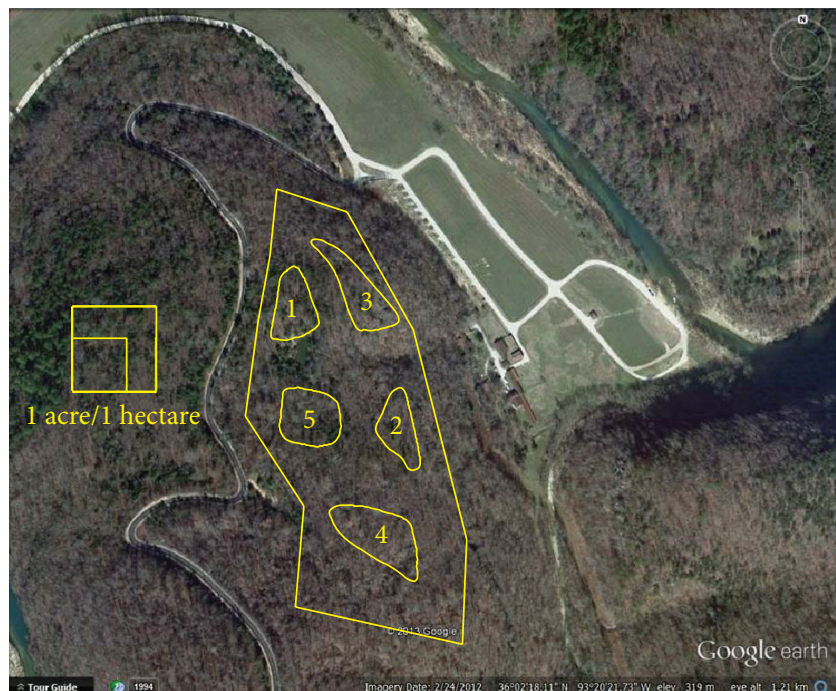

Figure 2: Overhead view of the field site at Steel Creek, with approximate limits of the site and blocks and acre/hectare scales in yellow. Base image taken from Google Earth [29].

The flight period of $M$. tuber lasts throughout the summer with some variation depending on latitude. They have been reported to occur in June through October in Connecticut [27], June through September in Maryland [28], July through September in Ohio [26], May through September in Alabama [18], and April through December in Florida $[19,20]$.

Few studies have reported $M$. tuber in significant numbers, but, in those that do, the sex ratio appears to be female biased. Scarbrough [30] collected 8 males and 18 females (1 male: 2.25 females) in two Malaise traps over a period of three years. Maier [27] collected 26 males and 43 females (1 male $: 1.65$ females) in a single Malaise trap over three years. Barrows and Flint [28], in six Malaise traps over the course of seven months, caught no males and 35 females. Johnson [26], in a single Malaise trap over two years, caught 61 males and 102 females ( 1 male: 1.67 females), the largest number of earwigflies yet reported from a single site. It is not known whether the sex ratio is truly skewed or if sampling bias is the cause.

Unlike life history, much is known about the morphology of M. tuber, with both internal and external anatomy of both sexes being well documented [31-34]. Males have elongated genital styli (= claspers) that are thought to be used in mating

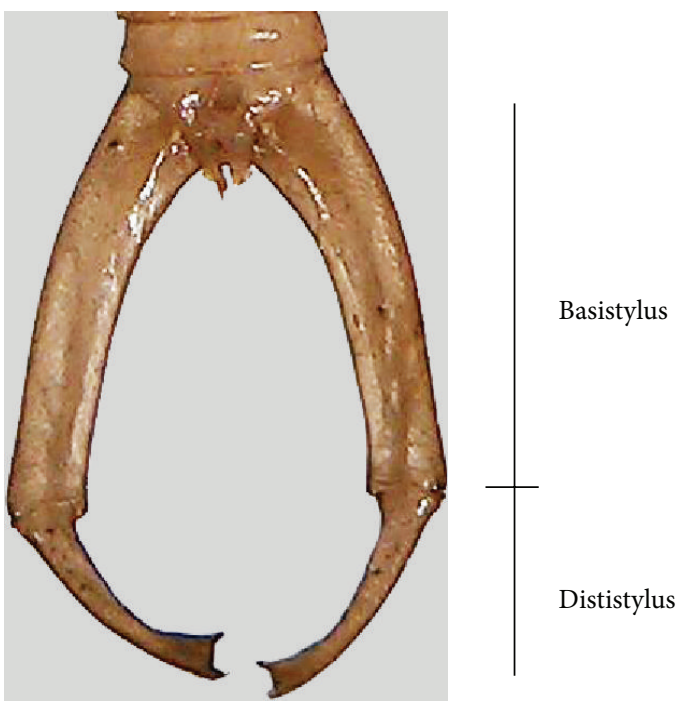

Figure 3: Clasper of male Merope tuber with basistylus and dististylus labeled.

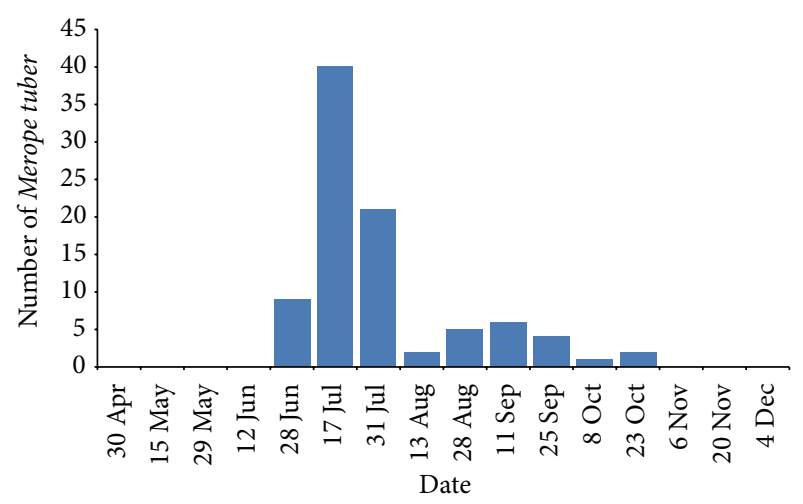

FIGURE 4: Number of Merope tuber collected across all traps per date.

as in other Mecoptera, either holding the female during copulation, fighting rival males, or both [26]. A bimodal distribution in clasper size has been demonstrated for at least one population with differential mating strategies being suggested as a possible cause [26].

\section{Materials and Methods}

As part of a more extensive arthropod sampling project, five blocks were established at a 4 ha plot located at Steel Creek along the Buffalo National River in Arkansas (Figure 2). In each block, five pan traps (one of each color: blue, red, green, yellow, and white) were randomly arranged under a terrestrial Malaise trap (MegaView Science Co., Ltd., Taichung, Taiwan), which was placed in perceived flight paths. In addition, three Lindgren funnel traps (ChemTica Internacional, S.A., Heredia, Costa Rica) (one of each color: green, purple, and black) were suspended nonrandomly from large trees 4-10 meters from the ground in the lower canopy. 
TABLE 1: Total number of Merope tuber collected per trap type per block, with subtotals of trap type and block.

\begin{tabular}{|c|c|c|c|c|}
\hline & Block & Number of females caught & Number of males caught & Total caught \\
\hline \multicolumn{5}{|l|}{ Trap type } \\
\hline Malaise trap & 1 & 0 & 0 & 0 \\
\hline Pan trap (purple) & 1 & 1 & 1 & 2 \\
\hline Pan trap (yellow) & 1 & 1 & 0 & 1 \\
\hline Pan trap (blue) & 1 & 0 & 0 & 0 \\
\hline Pan trap (white) & 1 & 1 & 0 & 1 \\
\hline Pan trap (red) & 1 & 0 & 0 & 0 \\
\hline Malaise trap & 2 & 0 & 1 & 1 \\
\hline Pan trap (purple) & 2 & 2 & 0 & 2 \\
\hline Pan trap (yellow) & 2 & 1 & 0 & 1 \\
\hline Pan trap (blue) & 2 & 2 & 1 & 3 \\
\hline Pan trap (white) & 2 & 2 & 1 & 3 \\
\hline Pan trap (red) & 2 & 4 & 1 & 5 \\
\hline Malaise trap & 3 & 0 & 0 & 0 \\
\hline Pan trap (purple) & 3 & 2 & 0 & 2 \\
\hline Pan trap (yellow) & 3 & 0 & 0 & 0 \\
\hline Pan trap (blue) & 3 & 0 & 1 & 1 \\
\hline Pan trap (white) & 3 & 1 & 0 & 1 \\
\hline Pan trap (red) & 3 & 1 & 1 & 2 \\
\hline Malaise trap & 4 & 0 & 0 & 0 \\
\hline Pan trap (purple) & 4 & 5 & 3 & 8 \\
\hline Pan trap (yellow) & 4 & 8 & 2 & 10 \\
\hline Pan trap (blue) & 4 & 7 & 3 & 10 \\
\hline Pan trap (white) & 4 & 2 & 2 & 4 \\
\hline Pan trap (red) & 4 & 2 & 1 & 3 \\
\hline Malaise trap & 5 & 1 & 0 & 1 \\
\hline Pan trap (purple) & 5 & 2 & 3 & 5 \\
\hline Pan trap (yellow) & 5 & 5 & 1 & 6 \\
\hline Pan trap (blue) & 5 & 2 & 1 & 3 \\
\hline Pan trap (white) & 5 & 4 & 0 & 4 \\
\hline Pan trap (red) & 5 & 2 & 1 & 3 \\
\hline \multicolumn{5}{|l|}{ Trap subtotal } \\
\hline Malaise trap & - & 1 & 1 & 2 \\
\hline Pan trap (purple) & - & 12 & 7 & 19 \\
\hline Pan trap (yellow) & - & 15 & 3 & 18 \\
\hline Pan trap (blue) & - & 11 & 6 & 17 \\
\hline Pan trap (white) & - & 10 & 3 & 13 \\
\hline Pan trap (red) & - & 9 & 4 & 13 \\
\hline \multicolumn{5}{|l|}{ Block subtotal } \\
\hline- & 1 & 3 & 1 & 4 \\
\hline- & 2 & 11 & 4 & 15 \\
\hline- & 3 & 4 & 2 & 6 \\
\hline- & 4 & 24 & 11 & 35 \\
\hline- & 5 & 16 & 6 & 22 \\
\hline Total & - & 58 & 24 & 82 \\
\hline
\end{tabular}


TABLE 2: Minimum, maximum, and mean measurements of various body parts and results of Shapiro-Wilk goodness-of-fit tests on the same. $P<0.05$ is considered significant. Significant values are indicated by an asterisk $\left({ }^{*}\right)$.

\begin{tabular}{|c|c|c|c|c|c|c|c|}
\hline Measurement & Sex & Minimum (mm) & Maximum (mm) & Mean $(\mathrm{mm})$ & $\mathrm{SD}(\mathrm{mm})$ & $W$ & Prob. $<W$ \\
\hline Head width & Female & 0.8 & 1.32 & 1.1 & 0.12 & 0.97 & 0.247 \\
\hline Pronotum width & Female & 1.06 & 1.69 & 1.41 & 0.16 & 0.97 & 0.196 \\
\hline Forewing length & Female & 8.86 & 13.28 & 11.66 & 0.9 & 0.98 & 0.337 \\
\hline Abdomen length & Female & 4.1 & 8.96 & 6.44 & 1.3 & 0.97 & 0.153 \\
\hline Head width & Male & 0.77 & 1.39 & 1.11 & 0.15 & 0.96 & 0.534 \\
\hline Pronotum width & Male & 0.95 & 1.63 & 1.31 & 0.17 & 0.97 & 0.756 \\
\hline Forewing length & Male & 9.52 & 13.39 & 11.82 & 1.04 & 0.971 & 0.695 \\
\hline Abdomen length & Male & 4.07 & 7.61 & 5.8 & 0.78 & 0.95 & 0.206 \\
\hline Basistylus length & Male & 2.21 & 5.09 & 4.05 & 0.77 & 0.95 & 0.265 \\
\hline Dististylus length & Male & 1.47 & 2.91 & 2.34 & 0.43 & 0.91 & $0.036^{*}$ \\
\hline Clasper total length & Male & 3.68 & 7.97 & 6.38 & 1.17 & 0.94 & 0.138 \\
\hline
\end{tabular}

Four blocks contained a SLAM (Sea, Land, and Air Malaise, MegaView Science Co., Ltd., Taichung, Taiwan) trap (with top and bottom collectors counted as separate traps). Three blocks contained pitfall trap sets placed every five meters along a transect centered on a Malaise trap. Two of these blocks contained eight pitfall trap sets and one block contained a single set.

Pitfall traps were modified from a design proposed by Nordlander [35], which Lemieux and Lindgren [36] demonstrated that it catches carabids in similar numbers but is more efficient at excluding small vertebrate bycatch. Rather than cutting circular entrances in the sides of pitfall traps, we cut three slots, $2 \mathrm{~cm}$ tall $\times 9.3 \mathrm{~cm}$ wide and $2 \mathrm{~cm}$ under the rim in the sides of plastic soup containers leaving three $1.5 \mathrm{~cm}$ posts, equidistant apart, resulting in a $28 \mathrm{~cm}$ collecting surface. Diameter at the base of slots is approximately $10.5 \mathrm{~cm}$ and the cups are $10.5 \mathrm{~cm}$ deep below these slots, resulting in a collecting volume of $2,988 \mathrm{~cm}^{3}$. This allowed the matching lid to be secured to the cup instead of using a separate cover. A single cup was placed on either side of a $30.5 \mathrm{~cm} \times 15.5 \mathrm{~cm}$ aluminum fence to make a pitfall trap set and the catch from both cups was combined and treated as a single sample.

Propylene glycol (Peak RV \& Marine Antifreeze) (Old World Industries, LLC, Northbrook, IL) was used as a preservative in all trap types. Traps were placed on March 13, 2013, taken down on December 4, 2013, and collected approximately every two weeks. Trap catch was sieved in the field and stored in Whirl-Pak bags (Nasco, Fort Atkinson, WI) in $90 \%$ ethanol until sorting. After sorting, specimens were stored individually in $2 \mathrm{~mL}$ microtubes (VWR International, LLC, Randor, PA) in 70\% ethanol. Voucher specimens have been submitted to the University of Arkansas Arthropod Museum.

Head width, pronotum width, wing length, and abdomen length were measured for both sexes. The lengths of the basistylus and dististylus (Figure 3) were measured on the right side of males and combined to measure total clasper length.

Measurements were made in the following manner: photographs of a millimeter ruler and dorsal and ventral aspect of each specimen were taken through the eye piece of a Leica MZ 16 stereomicroscope with the camera on an HTC
Droid Incredible 4 G LTE; zoom was not adjusted between photographs to ensure they were to the same scale. All photographs were exported onto a desktop computer, opened in ImageJ [37], and measurements were taken by tracing the structures. Measurements were recorded in Microsoft Excel (Redmond, WA).

Shapiro-Wilk goodness-of-fit tests $(\alpha=0.05)$ were performed in JMP (SAS Institute, Cary, NC) to test normality of previously described measurements. An F-test for significance was performed by creating a generalized linear model (GLM) with a Gaussian distribution $(\alpha=0.05)$. Count data were not normally distributed and required transformation. Because the data contained many zeroes, one was added to each count and before a natural log transformation. Because five pan traps were placed with a single Malaise trap, trap types could not be compared due to extremely skewed sample sizes. Instead, Malaise traps were considered a "color" in analyses and tested against each pan trap color. This simultaneously allowed for comparisons among variables of equal sample sizes for both trap type and pan color.

\section{Results and Conclusions}

All totaled eighty-two earwigflies-24 males and 58 females (1 male : 2.42 females) - were collected (Table 1$)$. This femalebiased collection is in line with previous studies [26-28,30]. Earwigflies were first collected in late June, with the largest collection occurring in July, followed by low, but consistent, numbers caught until late October (Figure 4). The beginning and end of the flight period were consistent with other areas at similar latitudes [19, 26-28].

Only a single body measurement, the dististylus, differed significantly from a normal distribution, but not in a bimodal manner (Table 2). These results are in contrast to previous studies, which found a bimodal distribution in the size of male basistyli, dististyli, and total clasper length [26]. As the use of the claspers is unknown, the significance of this is also unknown.

Earwigflies were not caught in SLAM traps, Lindgren funnel traps, or pitfall trap sets; therefore, these traps were excluded from analyses. Significantly fewer $M$. tuber were caught in Malaise traps compared to pan traps $(t=-2.455$, 
d.f. $=1, P=0.0145$ ), although pan trap colors were not significantly different from each other. This is the first report of earwigflies being collected in pan traps; however, previous studies which reported large collections of $M$. tuber traditionally used Malaise traps alone. It should be noted that, because pan traps were directly under Malaise traps, it is unknown whether those pan trap-collected individuals would have been captured in the Malaise trap collecting head, had pan traps not been present.

Significantly more earwigflies were caught in blocks 4 $(t=4.307$, d.f. $=1, P=0.00002)$ and $5(t=2.479$, d.f. $=1$, $P=0.0136)$ than in blocks 1,2 , and 3 . This suggests that trap placement and microhabitat, even within a relatively small area of a few hectares, are important factors when collecting earwigflies. If earwigflies are specifically targeted, we suggest placing multiple traps in an area of known occurrence in order to maximize the microhabitats sampled and increase the chance of collecting these enigmatic insects.

\section{Conflict of Interests}

The authors declare that there is no conflict of interests regarding the publication of this paper.

\section{Acknowledgments}

The authors thank Danielle Fisher for her assistance in sorting samples. This project and the preparation of this publication were funded in part by the State Wildlife Grants Program (Grant no. T39-05) of the U.S. Fish and Wildlife Service through an agreement with the Arkansas Game and Fish Commission.

\section{References}

[1] H. S. Barber, "The occurrence of the earwig-fly, Merope tuber Newman," Proceedings of the Entomological Society of Washington, vol. 1, no. 1, pp. 50-51, 1904.

[2] J. L. Pechal, M. E. Benbow, and J. K. Tomberlin, "Merope tuber newman (mecoptera: meropeidae) collected in association with carrion in greene county, Ohio, USA: an infrequent collection of an elusive species," The American Midland Naturalist, vol. 166, no. 2, pp. 453-457, 2011.

[3] R. J. P. Machado, R. Kawada, and J. A. Rafael, "New continental record and new species of Austromerope (Mecoptera, Meropeidae) from Brazil," ZooKeys, vol. 269, pp. 51-65, 2013.

[4] F. J. Killington, "A new genus and species of Meropeidae (Mecoptera) from Australia," The Entomologists Monthly Magazine, vol. 69, pp. 1-4, 1933.

[5] V. Novokschonov, "Der älteste vertreter der meropeidae (Mecoptera, Insecta)," Palaeontologische Zeitschrift, vol. 69, pp. 149-152, 1995.

[6] A. P. Rasnitsyn, "Taxonomic names, in new Mesozoic and Cenozoic Protomecoptera," Paleontological Journal, vol. 8, pp. 493-507, 1974.

[7] V. G. Novokshonov, "Scorpion flies of the family Permochoristidae, the closest common ancestors of extant scorpion flies (Insecta, Panorpida-Mecopera)," Zoologischeskii Zhurnal, vol. 73, no. 7-8, pp. 58-70, 1994.
[8] H. Weidner, "Merope tuber Newman in Canada," in Entomologische Mitteilungen aus dem Zoologischen Staatsinstitut und Zoologischen Museum Hamburg, vol. 3, pp. 45-46, 1964.

[9] D. K. B. Cheung, S. A. Marshall, and D. W. Webb, "Mecoptera of Ontario," Canadian Journal of Arthropod Identification, vol. 1, 2006.

[10] S. M. Paiero, S. A. Marshall, P. D. Pratt, and M. Buck, "Insects of Ojibway Prairie, a southern Ontario tallgrass prairie," in Arthropods of Canadian Grasslands. Volume 1: Ecology and Interactions in Grassland Habitats, J. D. Shorthouse and K. D. Floate, Eds., pp. 199-225, Biological Survey of Canada, Ontario, Canada, 2010.

[11] J. W. Barnes, "Notes on Minnesota Mecoptera," Entomological News, vol. 67, pp. 191-192, 1956.

[12] D. W. Webb, N. D. Penny, and J. C. Marlin, “The Mecoptera, or scorpionflies, of Illinois," Illinois Natural History Survey Bulletin, vol. 31, no. 7, pp. 250-316, 1975.

[13] G. W. Byers, "Autumnal Mecoptera of Southeastern United States," University of Kansas Science Bulletin, vol. 55, pp. 57-96, 1993.

[14] G. W. Byers, "Descriptions and distributional records of American Mecoptera. III," Journal of the Kansas Entomological Society, vol. 46, pp. 362-375, 1973.

[15] C. C. Coffman, "Merope tuber Newman (Mecoptera: Meropeidae) records from West Virginia collections," Proceedings of the West Virginia Academy of Science, vol. 54, pp. 48-53, 1982.

[16] D. E. Bowles and R. W. Sites, "Merope tuber (Mecoptera: Meropeidae) from the Interior Highlands of the United States," Entomological News, vol. 123, no. 2, pp. 155-160, 2013.

[17] H. W. Robison, G. W. Byers, and C. A. Carlton, "Annotated checklist of the Mecoptera (Scorpionflies) of Arkansas," Entomological News, vol. 108, no. 4, pp. 313-317, 1997.

[18] T. L. Schiefer and J. C. Dunford, "New state record for Merope tuber Newman (Mecoptera: Meropeidae) in Alabama," Journal of Entomological Science, vol. 40, no. 4, pp. 471-473, 2005.

[19] J. C. Dunford, P. W. Kovarik, L. Somma, and D. Serrano, "First state records for merope tuber (Mecoptera: Meropeidae) in Florida and biogeographical implications," Florida Entomologist, vol. 90, no. 3, pp. 581-584, 2007.

[20] L. A. Somma, "New collections and record for earwigflies and scorpionflies (Mecoptera: Meropeidae and Panorpidae) in Florida," Insecta Mundi, vol. 165, pp. 1-4, 2011.

[21] G. W. Byers, "Zoogeography of the Meropeidae (Mecoptera)," Journal of the Kansas Entomological Society, vol. 46, pp. 511-516, 1973.

[22] G. W. Byers, "Order Mecoptera. Scorptionflies and hangingflies," in Borror and DeLong's Introduction to the Study of Insects, C. A. Triplehorn and N. F. Johnson, Eds., pp. 662-668, Thomson Brooks/Cole, Belmont, Calif, USA, 7th edition, 2005.

[23] G. W. Byers and R. Thornhill, "Biology of the Mecoptera," Annual Review of Entomology, vol. 28, pp. 203-228, 1983.

[24] E. Jara-Soto, C. Mu, V. Jerez, and C. Muñoz-Escobar, "Registro de Notiothauma reedi McLachlan, 1877 (Mecoptera: Eomeropidae) en cádavers de vertebrados en la Comuna de Concepción, Chile," Revista Chilena de Entomología, vol. 33, pp. 35-40, 2007.

[25] P. M. Sanbourne, "Stridulation in Merope tuber (Mecoptera: Meropeidae)," The Canadian Entomologist, vol. 114, no. 3, pp. 177-180, 1982.

[26] N. F. Johnson, "Variation in male genitalia of Merope tuber Newman (Mecoptera: Meropeidae)," Journal of the Kansas Entomological Society, vol. 68, no. 2, pp. 224-233, 1995. 
[27] C. T. Maier, "Habitats, distributional records, seasonal activity, abundance, and sex ratios of Boreidae and Meropeidae (Mecoptera) collected in New England," Proceedings of the Entomological Society of Washington, vol. 86, no. 3, pp. 608-613, 1984.

[28] E. M. Barrows and O. S. Flint Jr., "Mecopteran (mecoptera: Bittacidae, meropeidae, panorpidae) flight periods, sex ratios, and habitat frequencies in a united states mid-atlantic freshwater tidal marsh, low forest, and their ecotone," Journal of the Kansas Entomological Society, vol. 82, no. 3, pp. 223-230, 2009.

[29] “Steel Creek," 36॰02'18.11“N, 93॰20’21.73”W, Google Earth, 2012.

[30] A. G. Scarbrough, "Recent collection records of Merope tuber Newman (Mecoptera: Meropeidae) in Maryland," Proceedings of the Entomological Society of Washington, vol. 82, no. 1, pp. 153$154,1980$.

[31] E. Potter, "Internal anatomy of the order Mecoptera," Transactions of the Entomological Society of London, vol. 87, pp. 467-501, 1938.

[32] G. W. Byers, "Type specimens of Nearctic Mecoptera in European museums, including descriptions of new species," Annals of the Entomological Society of America, vol. 55, pp. 466-476, 1962.

[33] A. Kaltenbach, "Mecoptera (Schnabelhafte, Schnabelfliegen)," Handbuch der Zoologie, vol. 4, no. 2, pp. 1-111, 1978.

[34] F. Friedrich, H. Pohl, F. Beckmann, and R. G. Beutel, “The head of Merope tuber (Meropeidae) and the phylogeny of Mecoptera (Hexapoda)," Arthropod Structure and Development, vol. 42, no. 1, pp. 69-88, 2013.

[35] G. Nordlander, "A method for trapping Hylobius abietis (L.) with a standardized bair and its potential for forecasting seedling damage," Scandinavian Journal of Forest Research, vol. 2, pp. 199-213, 1987.

[36] J. P. Lemieux and B. S. Lindgren, "A pitfall trap for large-scale trapping of Carabidae: comparison against conventional design, using two different preservatives," Pedobiologia, vol. 43, no. 3, pp. 245-253, 1999.

[37] C. A. Schneider, W. S. Rasband, and K. W. Eliceiri, "NIH Image to ImageJ : 25 years of image analysis," Nature Methods vol. 9, pp. 671-675, 2012, http://www.nature.com/nmeth/journal/v9/ n7/full/nmeth.2089.html. 

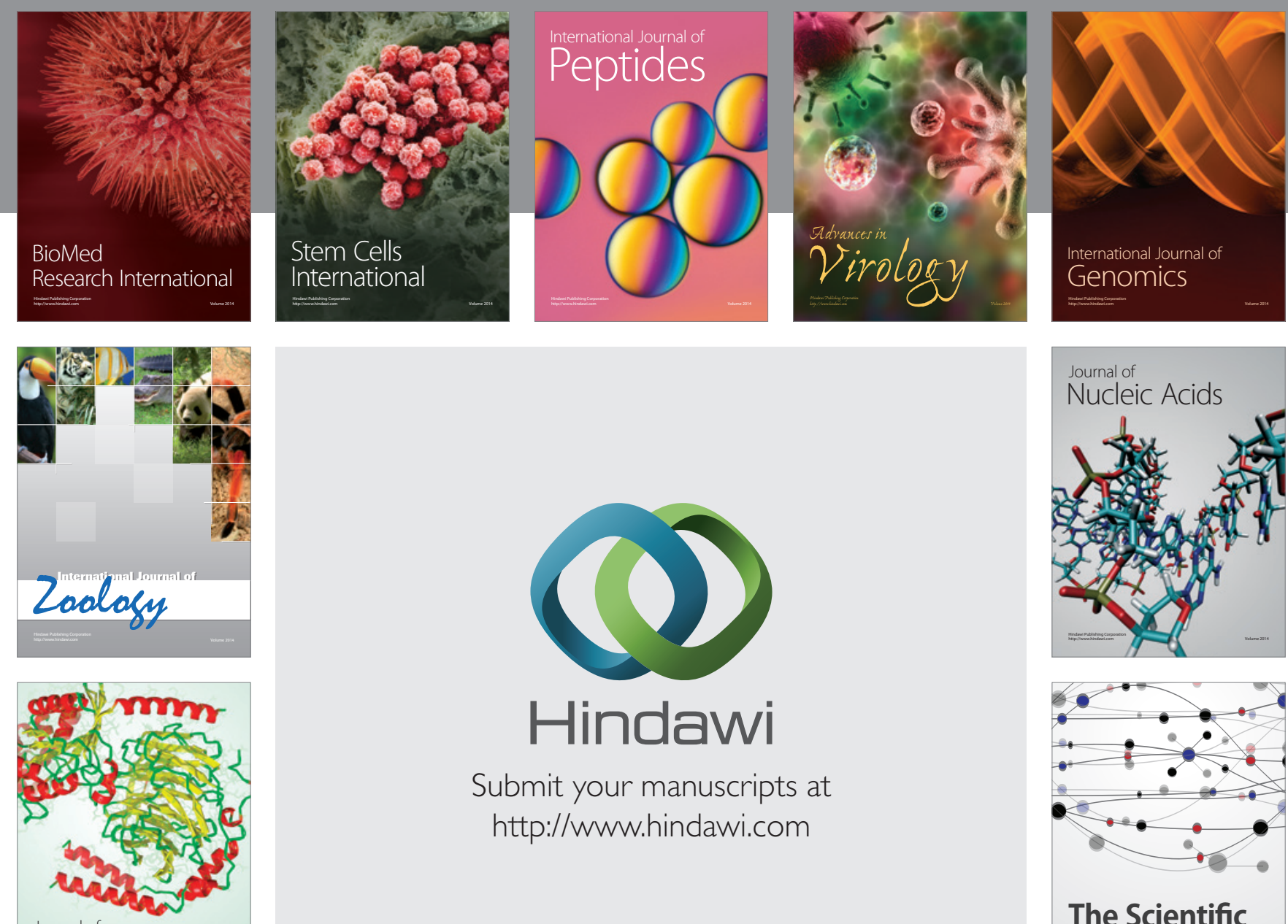

Submit your manuscripts at

http://www.hindawi.com

Journal of
Signal Transduction
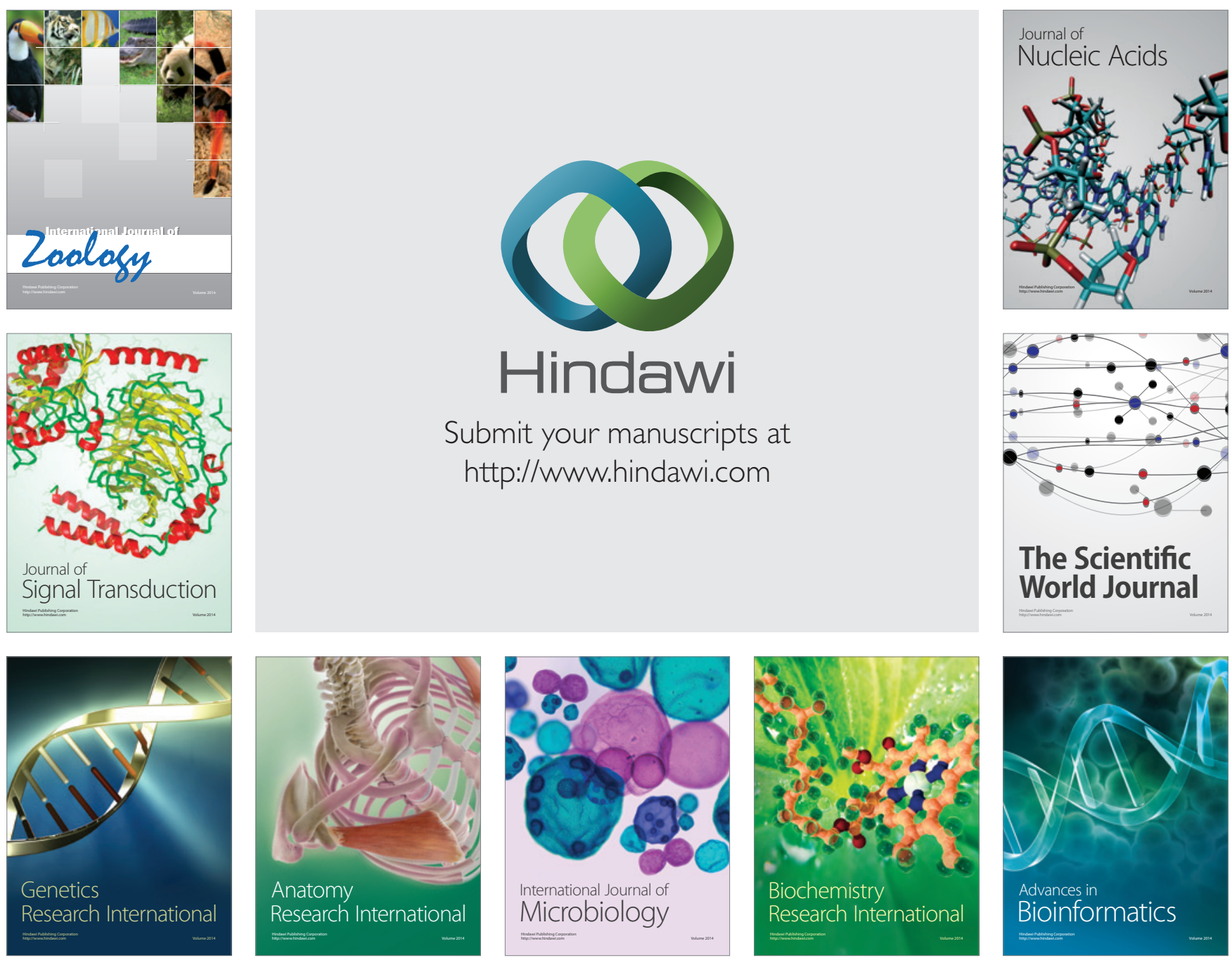

The Scientific World Journal
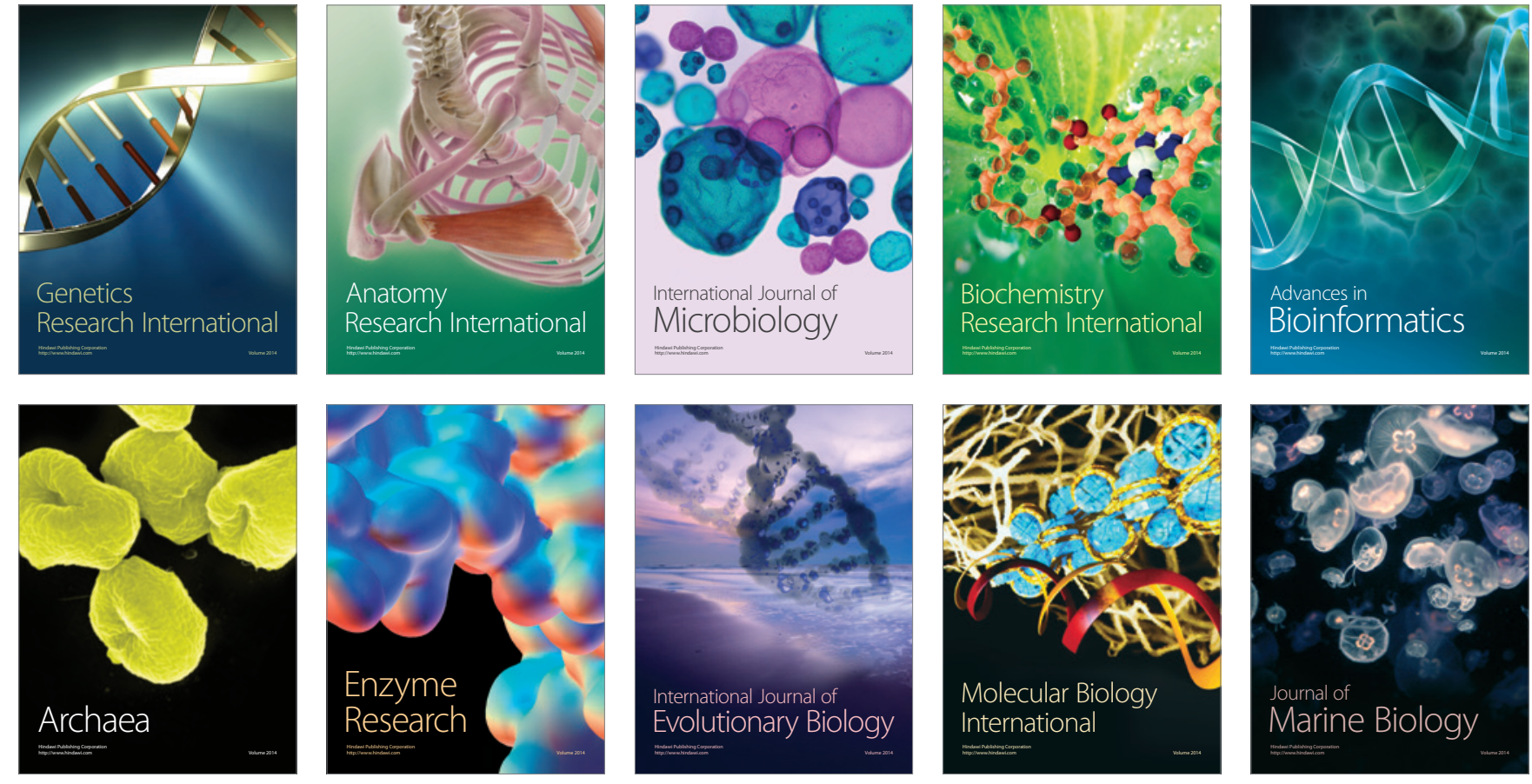